\title{
Game Based Learning Platform as a Tool for Assessment in Chemistry Education: Students' Experiences and Perspectives
}

\author{
$1^{\text {st }}$ Munasprianto Ramli ${ }^{1}, 2^{\text {nd }}$ Media Putri Yohana ${ }^{1}, 3^{\text {rd }}$ R. Ahmad Zaky El Islami ${ }^{2}$ \\ \{munasprianto.ramli@uinjkt.ac.id ${ }^{1}$ \} \\ Universitas Islam Negeri Syarif Hidayatullah Jakarta ${ }^{1}$, Universitas Sultan Ageng Tirtayasa ${ }^{2}$
}

\begin{abstract}
This study aims to explore student' experiences and perspective on using Kahoot!, a game based learning platform as an assessment tools in chemistry education. A descriptive qualitative approach utilised for this research. The study carried out at two analytical chemistry classrooms at Syarif Hidayatullah State Islamic University Jakarta. The researchers used Kahoot! every two weeks during the period of four month as a tool for formative assessment. Three students form each classroom were interviewed to explore their experiences and perception on using this game-based learning platform. The data from interviews were analysed using thematic analysis. The finding indicates that the students felt nervous when they were assessed using game-based learning platform since they knew their scores straight away and they were timed to do the assessment. However, they felt motivated to be a top scorer student. Moreover, they see beneficial of Kahoot and want to employ this platform in their classroom when they become a teacher.
\end{abstract}

Keywords: Kahoot!, formative assessment, game-based learning,

\section{Introduction}

Assessment is an important and inseparable part of educational process. It is a systematic and continuous activity to collect, analyze, and interpret information about teaching and learning processes and results in achieving learning goals. As a systematic process, assessment must be carried out in a planned and gradual manner in order to obtain an overview of student development. Meanwhile as a continuous process, assessment must be carried out continuously throughout the learning period [1].

Generally, there are two type of assessment in learning processed, called summative and formative assessment. Summative assessment is a usually done after all the subject matter has been taught. This assessment will be in the form of numbers or letters that are used as decisions on student performances. Summative assessment is designed to record students' overall achievement systematically. The purpose of summative assessment is to measure students' abilities and understanding, as a means of providing feedback to students at the conclusion of an instructional period like a unit, term and program [2][3].

Formative assessment is an assessment carried out to monitor student performances during the learning process. This assessment will provide feedback for the improvement of the learning process. Teachers are able to identify misconceptions and learning gaps along the learning process by implementing formative assessment [4]. The purpose of formative 
assessment is not only to determine the level of student ability but also to improve the learning process. In addition, Formative assessment aims to obtain information about how the learning process takes place in the classroom. This information will then be useful for teachers to improve, change or modify learning to be more effective in improving student competencies $[5]$.

Nowadays, in the midst of the rapid development of information technology, teachers are beginning to authorize the use of technology as a tool for formative assessment. One of technologies integrated in the classroom as a formative assessment tool is a games based learning platform such as Kahoot!. This study aims to explore student experiences and perception on using Kahoot! as assessment tools

\section{Game Based Learning Platform as Assessment Tool}

Students reply positively to mastering activities that allow them to interact with their teacher and others and get hold of immediately feedback. Various studies investigated that the usage of technology, along with computers, tablets, and smartphones, is positive in improving students' engagement and lively participation in classrooms. The use of personal devices and systems can enhance teachers' competencies to solicit participation from all students in their lessons. Using technology can be an exquisite way to interact students in today's classrooms. Computer lab and computer system in the classroom can be used in a similar manner if students do not have get entry to personal devices [6].

Game-based learning is considered as one of best practice in teaching and learning process. Previous studies have reported that games-based learning as an effective tool for educators to use in the classroom. The tool engages students in critical thinking, problem solving and review of content knowledge. It can be used to engage students in reviewing the content that they have learned in meaningful and fun way. With the rapid grow of technology, teachers should consider all of the possibilities and benefits that can be gained through using technology during the lessons. Researchers suggested that students should be enticed by the competitive nature of the game if it is going to be a valuable learning experience for the students. It would be a great beneficial for students using digital games in the classroom, It will support students to handle success and failure as well as how to use critical thinking and problem-solving skills. Thus, Kahoot! one of digital games platform can be used in higher education course to engage students with the knowledge content in a fun way [7].

Kahoot!

Kahhot! is a free game-based learning platform that engage students through game in the form of quizzes create by teachers. Students do not need this platform account to access quizzes that created by their teacher. To access the quiz, they only need to launch their kahoot!apps or kahoot.it and the PIN code which is displayed on the screen.

Meanwhile, to be able to employ Kahoot! in the classroom, teacher need to register or have a Kahoot! account. Soon after they have an account they can create a new quiz. It is realy easy and quick job to create a quiz [7]. The steps of creating the quiz is available through video tutorial and easy to follow.

After developing the quiz, teachers log into their account and retrieve their created quiz by clicking the bar "My Kahoot". Then, by launching the quiz, teachers will receive a pin code. Student should type the pin and submit their name to enter the quiz. Teachers manage 
the tempo of the quiz whether or not each student has the full time to answer the question before transferring on to the next available question. Questions are displayed on the screen with four answer options that students can choose. Students have to choose the answer by selecting colour and symbol on their device that matches the colour and symbol on the screen. Once the time allocated for answering each question is finish, the correct answer is displayed along with the graph showing how many people select each of four possible answers. Points are awarded for correct answer as well as how quickly students answer the questions. The fastest student who select correct answer will receive the highest point. The names of the top three students are displayed on the screen, while each student know their ranking on their own device $[7,8,9,10]$

\section{Research Methods}

Given the fact that the present study aims to explore students' experiences and perception on using game-based learning platform as a tool of, a descriptive qualitative is a suitable approach for this study. The researchers carried out this study at two classes of Analytical Chemistry at Chemistry Education Department State Islamic University Jakarta. The researchers selected the classes using a purposive sampling strategy since the researchers has access to these two classes.

The data were gathered using interview. The main purpose of the interview is to gather information from the respondent; to see things from the participant's perspective [11]. In addition to this primary purpose, interview can be used to identify variables and their relationship and to support findings from other research methods. And for this present study, interviewing was chosen as one method because researchers can generate contextual information on students' experiences and perception about the usage of Kahoot! as an alternative tool for formative assessment. Researchers interviewed 6 students from the analytical chemistry lesson, 3 form each class at the end of the term.

Beside interviews, researchers employed classroom observation. Observation is an important primary source of data for qualitative research. Scholars suggests that participant observation is the best methods when activities, event and situation can be seen first-hand $[11,12]$. In order to analyse classroom observation, researchers should write and record their observation. Considering the advantages and disadvantages of recording process of classroom observation, the researchers wrote a field note for each observation and recorded the observation using audio and video recorder. In total, the researchers observed 8 lessons within the period of four months.

Data gathered then analysed by employing thematic analysis approach. Thematic analysis is an approach for identifying, analysing and reporting themes rise from the data in qualitative data $[12,13,14,15]$ The thematic analysis method applied in this study is the one which developed by Braun and Clarke in 2006. Thematic analysis steps applied were familiarisation the data, initial code generation, searching for themes, reviewing themes, defining and naming themes and report writing [13]

\section{Findings and Discussion}

\subsection{Students' Experience}


Analytical chemistry course was the first course that applied Kahoot! as a formative assessment tool. Students had mixed feeling when using this game-based learning platform for the first time, as shown below

"Nervous yet excited. Initially, I wasn't sure whether I can

answer the question or not and I was afraid the internet would be suddenly disconnected. In overall, Kahoot is really challenging" (student $\# 1$ )

"I feel so challenged considering each question has time limit. I was also afraid of mistakenly pressing wrong answer button because I got panic" (student\#3)

"Panic and uncomfortable at the beginning. Because we race with a little time, and when time runs out we can't continue." (student\#5)

As describe above, some students felt nervous and uncomfortable at the beginning. This feeling occurs due to the fact that they have to complete a question with a certain period of time and they should have a correct answer. These conditions led them to the under-pressure situation that they had to deal with. Meanwhile, some students felt excited.

"I feel a bit nervous yet excited. I also wanted to be first one

who can answer the question" (student $\# 4$ )

"The test using Kahoot! is fun, because the atmosphere of

the test is like the atmosphere of playing

games."(student\#2)

Here, the students reveal that they were excited and seen Kahoot! as a fun platform to be implemented in the classroom. This experience was in line with the previous study which describe that Kahoot! is fun and engaging platform that valuable for students [7].

\subsection{Advantages and Disadvantages of Using Kahoot!}

Kahoot! is one of popular platforms that implemented in the classroom. This game-based learning offers many advantages, as shown below

"simpler, fun, challenging, paperless and make students

more focus" (student\#1)

"Kahoot! utilizes technology so that the assessment process

becomes more practical, it is also minimize the dishonesty

of test participants and the test has been more enjoyable

with Kahoot!" (student\#2)

"saves paper, saves time because each question has time

limit, is more practical because it does not require paper"

(student\#3)

"The advantages are more practical because the test results

can be seen immediately, demanding students to think

quickly" (student\#5)

As can be seen from above responses, it is clear that Kahoot! has many advantages when implemented in the classroom as a tool of formative assessment. Kahoot! is not only a simpler fun and engaging platform, but also more practical and help educators to save the environment since it is paperless. In addition Kahoot! is also able to help students more focus in learning. 
These results seem to be consistent with other research which found that Kahoot! is more effective, able to support educators in creating more engaging and motivating classroom atmosphere, and able to create environment that make students more focus in studying the topic [8].

Moreover, student also identified another advantage of Kahoot!. Kahoot! show the correct answer and score as a form of student feedback.

"After you answer the questions, you know the correct

answer as well as your score" (student\#3)

"It is good to have the feedback straight away. I mean you

know the correct answer and know your score" (student\#4)

The above responses shown that Kahoot! can offer direct feedback to student and they need them. It is important to know the feedback and score of formative assessment so then they will able to close the gap between what they know and what they expected to know. platform

However, students also recognized disadvantages of this promising game-based learning

"kahoot cannot be applied to areas that are constrained by

signals. The chance to give a wrong response could be

bigger because the participants were in a hurry, compared

to working on paper-based tests without a timer"

(student\#2)

"need a decent internet connection." (student\#4)

Students reveals that Kahoot! has two disadvantages when implementing in the classroom. The first disadvantages is that Kahoot! could not be applied when students or the class has limited internet connection. Sometimes students exit from the apps that make they lost their mark due to lost of internet connection. The second disadvantages according to students is that they need to do the test in a hurry since they are given certain time to answer the questions. As a result they may give the wrong response or answer since they feel underpressure.

\subsection{The Implementation of Kahoot! in the Near Future}

Considering the advantages offer by Kahoot!, all of participants were agree to implement Kahoot! in the near future when they carried out teaching internship. Specifically, one student commented that:

"Yes, because the assessment process becomes more

practical, fun, and motivating. Especially in the next few

years, when I become a teacher, my students will be the

ones who are called millennial generation. Kahoot will be

very suitable for them". (student\#2)

Even though Kahoot! is a novel formative assessment tool which suitable for $21^{\text {st }}$ century generation, this game-based platform cannot be implemented at all the topic lessons, as some participant response that :

"I will implement Kahoot depend on the topic learned"

(student\#5)

"I will be using Kahoot depend on the situation, condition and the subject" (student\#4) 
"I will use it for certain topics" (student\#1)

It is noteworthy that students concern about the implementation Kahoot in relate to the complexity of chemistry lesson. They believe that Kahoot! is a good alternative for formative assessment tool, however it cannot be implemented in all the topics covered in the chemistry classroom. It seems that Kahoot! is not suitable for topics that need more complex calculation and concept. These results are in agreement with previous study which identified that Kahoot! cannot be simplify the complex subject due to the nature of the topic [8].

\section{Conclusion}

Kahoot! is one of effective tools to promote engagement and motivation in learning. This game-based platform can be benefit for both students and educator. This study found that students felt nervous at the first time, and later on they felt excited and fun doing Kahoot!. Kahoot! offers enjoyable and meaningful learning with few limitation such as it is needed a decent internet connection and push students to work according to time allocate for each question. Considering the advantages, students were agreed to implement this amazing platform during their teaching internship in the near future. Based on this study, the researchers recommend teachers or educators to implement this platform in their classroom and further research is also needed to investigate the effectiveness of Kahoot! at schools and universities.

Acknowledgements. This paper in conjuction with The $4^{\text {th }}$ International Conference on Education in Muslim society (ICEMS 2018).

\section{References}

[1] J.A. Muskin, Continuous Assessment for Improved Teaching and Learning: A Critical Review to Inform Policy and Practice. IBE-UNESCO,2017.

[2] Centre for Educational Research and Innovation, Assessment for Learning: The Case for Formative Assessment. OECD, 2008.

[3] P. Bazelais, T. Doleck, and D.J. Lemay, "Exploring the Association Between Formative and Summative Assessments in a Pre University Science Program”. Journal of Formative Design in Learning, Vol 1, pp 65-72, 2017

[4] E.Trumbull and A. Lash. Understanding Formative Assessment Insights from Learning Theory and Measurement Theory San Fransisco: WestEd, 2013.

[5] D.J. Nicol and D. Macfarlane-Dick, "Formative Assessment and Self-regulated Learning: a Model and Seven Principles of Good Feedback Practice". Studies in Higher Education Vol.31 pp 199-218, 2006.

[6] K. Johns, "Engaging and Assessing Students with technology: A Review of Kahoot!". Policy and Practice Vol 81 No 4 p 89, 2015

[7] R. Dellos, Kahoot! A Digital Game Resource for Learning". International Journal of Instructional technology and Distance Learning Vol 12. No 4 pp 49-52, 2015

[8] M.A Ismail and J.A Mohammad, "Kahoot: A Promising Tool for Formative Assessment in Medical Education”. Education in Medical Journal Vol 9 No 2, 2017.

[9] H. Bicen and S. Kocakoyun, "Determination of University Students' Most Preferred Mobile Application for Gamification". World Journal on Educational Technology Vol 9 No, 2017 
[10] B. Taylor and E. Reynolds, "Building Vocabulary Skills and Classroom Engagement with Kahoot!. the $26^{\text {th }}$ Korean TESOL Conference, 2018.

[11] U. Flick An Introduction to Qualitative Research. Los Angeles: Sage Publications, 2009

[12] E.C Wragg An Introduction to Classroom Observation. London: Routledge, 2002

[13] R.E Boyatzis Transforming Qualitative Information. Cleveland: Sage Publications, 1998

[14] V. Braun and V. Clark, "Using thematic analysis in psychology", Qual. Res. in Psy. Vol. 3 pp. 77-101, 2006

[15] M. Dixon-Woods, S. Agarwal, D. Jones, B. Young, and A. Sutton, "Synthesizing qualitative and quantitative evidence: a review of Possible methods" Journal of Health Services Res. and Policy Vol. 10 pp 45-53, 2005 